\title{
International Financial Reporting Standards Adoption and Liquidity Performance of Food and Beverages Listed Companies: Empirical Evidence from Nigeria
}

\author{
Abubakar Sambo Junaidu ${ }^{\circledR}$ \\ Haruna Ahmadu ${ }^{2}$
}

${ }^{1,2}$ Faculty of Management Science, Usmanu Danfodiyo University, Sokoto, Nigeria.

Email:junaidu09@gmail.com

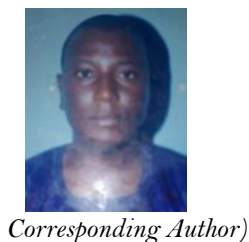

Abstract

Despite the relevance and adaptations of International Financial Reporting Standard (IFRS) in Nigeria, the literature indicates very few studies have attempted to investigate the effect of IFRS adoption to the firm's performance, specifically, the relationship between IFRS adoption and liquidity performance of food and beverages listed companies in Nigeria. The literature suggests that there is not only limited information on the impact of IFRS adoption but also little research in this important area of study. Based on this information and research gab, the objective for the study is to investigate the effect of IFRS adoption on liquidity performance of food and beverages listed companies in Nigeria. By using Secondary data was collected from the annual reports of the sample companies. Multiple ordinary least square (OLS) regression was used to analyse the data collected from the audited financial statements of the sampled companies. I-T test and J-T test were also applied to test for any significant increase in firm performance after the adoption of IFRS. The analysed result showed that there is significant relationship between IFRS adoption and liquidity performance of food and beverages companies listed in the NSE. The implication of this study is that, the practice of the adoption of IFRS should be given more emphasis by organisations in Nigeria. The finding of the study indicates that, organisations that adopt IFRS would be able to improve their liquidity performance.

Keywords: IFRS, Foods and beverages, Liquidity performance, Nigeria

Citation | Abubakar Sambo Junaidu; Haruna Ahmadu (2019). International Financial Reporting Standards Adoption and Liquidity Performance of Food and Beverages Listed Companies: Empirical Evidence from Nigeria. Growth, 6(1): 20-26. History:

Received: 3 July 2019

Revised: 12 August 2019

Accepted: 18 September 2019

Published: 29 October 2019

Licensed: This work is licensed under a Creative Commons

Attribution 3.0 License (cc) $\mathbf{E}$

Publisher: Asian Online Journal Publishing Group
Acknowledgement: Both authors contributed to the conception and design of the study.

Funding: This study received no specific financial support.

Competing Interests: The authors declare that they have no conflict of interests.

Transparency: The authors confirm that the manuscript is an honest, accurate, and transparent account of the study was reported; that no vital features of the study have been omitted; and that any discrepancies from the study as planned have been explained.

Ethical: This study follows all ethical practices during writing.

\section{Contents}

1. Introduction

2. Literature Review

3. Methodology

4. The Results .... 24

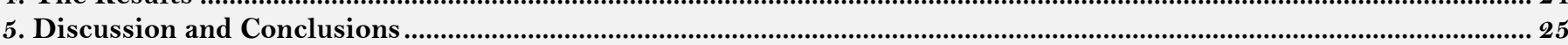

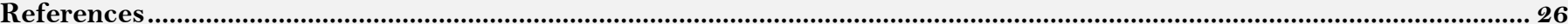




\section{Contribution of this paper to the literature}

This paper contributed to the literature by demonstrating the influence of international financial reporting standards adoption on liquidity performance of food and beverages listed companies. In addition, the paper implied owner's manager should adopt the adoption of IFRS for their liquidity performance to improve.

\section{Introduction}

It is indeed a milestone for accounting profession as countries of the world are moving towards a unified accounting and reporting standard which is the international financial reporting standard (IFRS). While countries like Germany, United States of America (USA) have for a long time been operating under IFRS; there are a number of developing countries also that adopted the system in the last few years and Nigeria is one of them. The model of IFRS theoretically lives under the hypothesis of improving performance evaluation, quality of reporting and clarity of concepts and elements in financial statement of companies. It is against this background that attracts researchers globally investigating the validity of such proclamations. Although not necessarily on a particular objective, different aspects of IFRS have been investigated. From adoption procedures and challenges; operating procedures and challenges; performance evaluation and reports quality among others have attract lots of interest of researchers all over the world and mixed results have been reported.

Since their inception, International Accounting Standards have been produced by two bodies. The first, the International Accounting Standards Committee (IASC) came up with 41 accounting standards between 1973 and 2000. The IASC was replaced by the International Accounting Standards Board (IASB) in the year 2000. The new Board embarked on a review processes aimed at refining the standards. The result was a reduction in the number of standards from 41 in the year 2000 to 28 by the year 2008. By 2011, 13 standards had been issued by the board as International Financial Reporting standards (IFRS). According to International Accounting Standard (IAS) Plus (2010) IFRS refers to the entire body of IASB pronouncements including standards and interpretations approved by IASB, IASC and their interpretations produced by the Accounting Standards Interpretations Committee (IASIC). IFRS or IAS have also been described as a set of standards stating how particular type of transactions and other events should be reflected in financial statements, issued by IASC and IASB (Outa, 2011). The primary objective of the accounting standards is to enable corporations to provide investors and creditors with relevant, reliable and timely information which is in line with the IASB's accounting framework for the preparation and presentation of Financial Statements. Such information, it is argued, contributes towards the achievement of orderly capital markets around the world (Imhofe, 2003). The concept of accounting quality is based on the IASB framework where relevance, reliability, understandability and comparability (Outa, 2011) are key components and therefore, assumed that financial statement with the four qualitative characteristics have better quality. Chen et al. (2010) has simply described accounting quality as the extent to which the financial statement information reflects the underlying economic situation.

Even though, IFRS adoption is considered as an important to the Nigerian listed firm's performance, there has not been much research focus on the IFRS adoption and liquidity performance of foods and beverages companies in Nigeria (Agyapong, 2015; Odhiambo et al., 2015). Previous studies on IFRS adoption focus on it effects to the value relevance, challenges and benefits of the adoption and impact of the IFRS adoption. Therefore, as an area of study, there is still not much information as well as research on IFRS adoption from foods and beverages companies' perspectives specifically related to liquidity performance. Given this information and research gaps, the objective of this paper is to examine the effect of IFRS adoption on the performance of foods and beverages companies in Nigeria. In doing this, the paper is presented in five sections. The following Section Two is literature review. Next, Section Three is research methodology, section four present the results of the analyses, Finally, Section five presents discussion conclusion of the paper.

\section{Literature Review}

International Financial Reporting Standards (IFRS) represent a set of accounting principles and guidance used by companies to prepare financial statements, a critical source of information published annually, at a minimum, and useful to various stakeholders in understanding a company's financial performance and management's stewardship of the company's resources. Developed by the International Accounting Standards Board (IASB), these are a set of accounting rules followed by, or being adopted by, more than 100 countries. All member states of the EU are required to use IFRS as adopted by the EU for listed companies since 2005. All other major economies have initiated a process to consider convergence or adoption of IFRS in the near future, even the United States (US GAAP as developed by the Financial Accounting Standards Board (FASB) - being the other most important set of financial reporting standards) where cross-listed firms on the US stock markets have been permitted to file statements prepared under IFRS since 2007. With the increasing globalisation of financial markets and of companies, the use of a single set of financial reporting standards across countries is viewed as having increased the comparability of financial statements across borders. It also reduces the cost of preparing the consolidated financial statements of groups made up of companies conducting business all around the world.

A study by Latridis (2010) undertook a comparative study between GAAP and IFRS in the United Kingdom in terms of quality reports of financial statement. Based on available data from companies listed on the UK's stock exchange, the author computed financial statement under GAAP and IFRS respectively. In addition, the econometric model of higher discretionary accruals (DAC) was employed for contrast investigations and for degree of results validity obtained under GAAP and IFRS computations. The results revealed that under IFRS, firms displayed higher book value of equity per share, profitability and leverage than under GAAP. Under IFRS, it also indicates lower volatility in liquidity than under GAAP. From all the standards of comparison and weight, the result under IFRS displayed higher quality of information on financial statement than under GAAP. The implication is that the model of IFRS is richer on comparative terms with other accounting and reporting 
standards that ever existed. The author recommended the need for other companies in UK to move towards IFRS even if it is voluntarily.

Daske and Gebhardt (2006) investigate the impacts of IFRS adoption on accounting quality in three European countries. These countries include Austria, Germany and Switzerland. As for their methods of data analysis, secondary data was employed for the annual reports of some selected companies across the three countries who have adopted IFRS. Their results revealed that quality of information, evaluation of performances, and definition of concepts are absolutely unmatched on comparative scale with other accounting and reporting standards that ever existed. The authors recommend other companies who are yet to decide or contemplating on going for IFRS should go for it.

Adejoh and Hasnah (2014) examine the quality of financial statement, information, and report on comparative scale between the Nigerian standard (SAS) and IFRS of some selected companies that were listed in the Nigerian stock exchange (NSE). Unlike the discovery in the work of Latridis (2010) their findings revealed mixed results; while few companies demonstrated advance quality of reports under IFRS than under SAS. However, on quantitative aspects, reports under SAS were more favourable. The authors were under the suspicion that for companies whose IFRS reports were less qualitative are either not complying with the rules of IFRS or lacked the skilful personnel who are familiar with the system. Against this background, the authors suggested the introduction of IFRS in the nation is learning institutions, training of personnel and workshops particularly on IFRS. This will enable the country to enjoy fully from the glories of IFRS like other nations.

Abdul-Baki et al. (2014) conducted a comparative study on performance of Oando Nigeria plc using financial ratios as measure of performance between IFRS and SAS based financial statements. The performance variables used are; profitability ratios, liquidity ratios, gearing ratios, stock market ratios, three ratios from each category. As for their methods of data analysis, the authors employed two different econometric models which include Kolmogorov-Smirnov-test and U-test. After their mathematical analysis, their results revealed that there is no significant difference between IFRS and SAS (GAAP) based ratios.

Ocansey and Enahoro (2014) did a comparative study from reviews of literature in terms of the progress and challenges between Nigeria and Ghana on IFRS from the day of adoption. Ghana in particular adopted the new international financial reporting standard (IFRS) in the year 2005 while Nigeria went for it in 2010 . The authors in their discovery revealed that both countries are on the same level especially on the issue of challenges. In both countries, the glories of IFRS are less as experienced in other parts of the world. As reported in their results, the major stumbling blocks confronting the success of IFRS in both countries includes the lacked of skilful manpower, experts in that area and the problems of compliance refusals. In their recommendations, the authors advocate for staff training, accreditation of IFRS in syllabus of tertiary institutions and the enactment of law that will provide severe punishment for lacked of compliance especially for companies listed on the capital markets of both countries.

Josiah et al. (2013) investigates the progress and challenges of IFRS in Nigeria adopted by the Nigerian financial reporting council (NFRC). As argued in their study, the model of IFRS is capable of increasing the direction of foreign direct investment (FDI) in Nigeria and the strengthening of investor confidence across the board. Aside such proclamations after their analysis, the results correlate with their proclamations theoretically, but in practical terms, it was the opposite. For substantiations, the quality of information displayed from financial statement prepared under IFRS were not clearer as obtained in other countries because of challenges such as compliance refusal and poor knowledge of IFRS. The authors recommended that financial reporting council (FRC) in Nigeria should come up with quick customization format and to be enacted into law along with penalties for compliance refusal, otherwise Nigeria will be left behind from global perspective and assurance of confidence continuity will never be unlikely to disappear on the horizon.

Oseni (2013) examine the application challenges of international financial reporting standard (IFRS) in Nigeria from some selected companies listed on the Nigerian capital market. His findings showed that compliance refusal, lacked of expertise, non-popularity of the system are the biggest stumbling blocks restricting the benefits of IFRS as enjoy by other countries. His recommendations include the staff training, mandatory compliance which must be supported by the national laws and public enlightens particularly on the benefits of the model. He was of the view that the nation's existing laws does not fully provide the enabling environment for full-fledge implementation, adoption and compliance as it is in other countries.

Adeyemi (2012) investigates the impacts of accounting standard of financial reporting in Nigeria on some selected companies listed on the Nigerian stock exchange (NSE). Having acknowledged the facts from evidences in other countries, on comparative terms Nigeria is still left behind. Nevertheless, within the Nigerian territory, the adoption of international financial reporting standards has produced better results and elevated confidence particularly on accounting, credibility, and acceptability of financial reports. However, the author's dissatisfaction from his discovery is the fact of measuring the success of IFRS on the global scale. For Nigeria to meet up these expectations in practical terms there is the need for more incentives for Nigerian companies to adopt IFRS as the one and only accounting and reporting model as it was done in other countries.

Kanu et al. (2014) investigates the compatibility of international financial reporting standard (IFRS) as for whether or not the ages of small and medium scale enterprises (SMEs) are due for the model. Using primary data obtained from administered questionnaires, which reflect the perceptions of Nigeria's professional accountants and managers of such companies. His results showed that within the body structure of SMEs in the country, they are face with problems that are still active which suggest that even if they should go for IFRS, the question of timing is of paramount importance. For substantiation, the business environment where SMEs operate in Nigeria will not be conducive for IFRS. The problems of manipulation, poor management and the lacked of clarity of ownership are still rich within SMEs. Their recommendations were that SMEs in Nigeria should in the first place address their structural and administrative challenges before going for IFRS, because there will come a time when it will be mandatory for all business companies operating in Nigeria irrespective of its size to use IFRS as recognized accounting and reporting standard.

Pius and Raymond (2014) examine the effects of international financial reporting standard (IFRS) for fourteen commercial banks operating in Nigeria and have been playing on the Nigeria's capital market. The study timeframe 
is between 2006 and 2012. Prior to the adoption of IFRS in 2010, the Nigerian commercial banks, generally use statement of accounting standard (SAS) in their financial reports. In 2010, it was made mandatory the adoption of IFRS from central bank (CBN) authorization. In comparison between the six years' regime of SAS and two years of IFRS on the scale of quality of information, definitions of terms and performance evaluation; their results show that IFRS regime, has superior characteristics at all levels over SAS.

Umobong and Akani (2015) conducted a comparative study on the impact of IFRS adoption on the market performance of food and beverages manufacturing firms in Nigeria. The study covers a period of 5years. The objective of the study was to find out whether there is difference between the performance of the companies before and after the adoption of IFRS. The variables used in the study were earning per share, Price earnings ratio and Dividend yield. T-test was used as the technique of data analysis. The study revealed that there is no significant difference between the market performance of firms before and after the adoption of IFRS.

Adeuja (2015) conducted a comparative study on the performance of banking industry in Nigeria between the IFRS and SAS period from 2010-2013. The variables controlled in the analysis were liquidity ratio, profitability ratio, leverage ratio and asset quality ratio. An independent T-test was used as the statistical technique of data analysis. The findings showed no statistically significant difference between the two accounting standards.

Taiwo and Adejare (2014) study the effect of International Financial Reporting Standards (IFRS) adoption on accounting practices in Nigeria. They adopted personal interview and questionnaire methods to collect primary data. They use Chi-square and ANOVA for analysis of data. They concluded that there is a strong relationship between the adoption of IFRS and financial performance due to cost reduction of an organisation and improved business efficiency and productivity. They recommended that the financial reporting practice in Nigeria should cut across the public and private sector to bring uniformity in accounting practice regarding annual preparation of financial reports to the owner of companies and other interested parties.

Nneka and Rotimi (2012) conducted a study on the extent to which the adoption of IFRS can enhance financial reporting system in Nigerian Universities. The population of the study comprises of 160 senior accountants and internal auditors. They adopted a survey design for the study and used descriptive statistics and multiple OLS regression. The findings of the study indicated that there are a lot of accounting areas the accountants and auditors should focus in discharging their duties. Mostly accountants, auditors, bursars, financial analyst, etc., are the personnel involve in the IFRS financial instruments. They recommended that the curricula of our institutions should be reviewed to incorporate IFRS so that students, accountants and auditors will be acquainted with IFRS guidelines and standards.

Donwa et al. (2015) conducted a study on the effect of IFRS on Accounting Ratios in Nigerian Oil and Gas companies. The study was embarked upon to find out if the adoption of IFRS leads to a significantly higher performance assessment of the Oil and Gas companies in Nigeria. The study compare financial ratios computed under NGAAP with those computed under IFRS for two years' period under each regime from 2010 to 2011 under NGAAP regime and 2012 to 2013 under IFRS regime. The mean differences between the two regimes were considered. Empirical analysis was performed to check if there were any significant differences between the ratios prepared under IFRS regime and NGAAP regime, using t-test Statistics. The result shows that the overall ratios of both short and long-term solvencies indicate higher liquidity for NGAAP dominated financial statement than the IFRS, except for debt to worth that showed a higher performance under IFRS while the profitability ratio was higher under IFRS regime, but there was no significant difference between the two regimes.

Adelusi and Ibigbami (2017) examined the effect of IFRS adoption on the profitability of selected quoted oil and gas companies in Nigeria. Their area of focus is liquidity, profitability and leverage of these companies using the Nigerian GAAPs and IFRS. The study employ secondary source of data using the financial reports of the five (5) selected oil and gas companies. The data was analysed using pair sample test statistics to compare pre and post IFRS adoption period. 2009 to 2011 was the pre IFRS adoption period and 2012 to 2014 was the post IFRS adoption period. The findings of the study show that there was no significant statistical difference in respect of the key performance indicators used in accessing the company's performance. They recommended that further study should be done to cover more periods after IFRS adoption.

Abdullahi et al. (2017) investigated the effects of international financial reporting standards (IFRS) adoption on the performance of oil and gas marketing companies in Nigeria. They purposively selected a sample of eight (8) oil and gas companies operating in the country due to availability of data. Firms' performances was represented by profit margin, return on assets and return on equity ratios and were considered as dependent variables to be determine by reporting regime as independent variable. They use current ratio, quick test, total debt ratio, earning per share and equity debt ratio as control variables. They computed and compare two years before IFRS adoption (2010 to 2011) and two years after IFRS adoption (2012 to 2013) ratios. OLS regression with the help of e-views 9 was used for data analysis. The study reveals that IFRS adoption has not improved the performance of oil and gas companies in Nigeria. The study recommended that oil and gas companies should continue to comply with IFRS provisions as it will improve their reporting quality which will also improve their performances as a result of more investments, easy access to capital and comparability

A critical review of literature highlighted most of the previous study that examined the IFRS adoption are predominantly focus on it effects to the value relevance, challenges and benefits of the adoption and impact of the IFRS adoption on performance of companies. In addition, most of these studies concentrate on the effects of IFRS adoption on the performance of banks and oil \& gas companies quoted on the NSE. There is therefore a need for more empirical studies that investigate the impact of IFRS adoption on the liquidity performance of Food \& Beverages companies listed, especially in Nigeria, where these firms are considered as important institutions to the country. Based on this information and research gap, the objective of this paper is to examine the impact of IFRS adoption on the liquidity performance of food and beverages companies listed in Nigeria. 


\section{Methodology}

This study adopts the survey design, as the data for the research was obtained from various audited annual financial statements of the food and beverages companies listed on the Nigerian Stock Exchange. Secondary data were collected from the audited annual financial statements of the sampled companies. The main source of data for this study was the annual financial reports and accounts of the sampled companies and the Nigerian Stock Exchange annual fact books.

A panel of eighteen (18) food and beverages companies, providing data for eight years' period was used (Panel of 144 audited annual reports). To examine the relationship between IFRS adoption and liquidity performance of food and beverages companies listed in the NSE, financial statements of the sampled companies were used to compute the various performance indices. The study employed financial ratios that are considered as performance indicators for data analysis. The aim is to capture the degree of confidence in line with the study's hypotheses. This strategy was considered necessary and relevant to our research objectives.

To analyse the data financial ratios of liquidity were used. Ratios were calculated based on figures obtained from financial statements that are prepared under the two sets of accounting standards (IFRS and SAS) for four separate years (2008-2011 for SAS and 2012-2015 for IFRS) respectively. To describe the data set measure of central tendency and measure of dispersion were used. Measure of central tendency used includes sampling mean and median, while measure of variability includes the minimum variable, maximum variable, and sampling standard deviation.

A paired sample t-test was used to test for the statistical significance of the difference in variance of the ratios under the two accounting standards. The decision rule is to reject the null hypothesis if the calculated $(\mathrm{t} / \mathrm{f})$ value falls outside the critical values or if the $\mathrm{p}$ value is less than 0.025 (critical value) at two tails. The relationship between IFRS and SAS ratios was analysed using multiple OLS regression analysis. Multiple OLS regression is useful in analysing categorical data, where the independent variable is dichotomous and takes only two values, that is 0 and 1.1 for IFRS reported financial numbers and 0 for SAS reported financial numbers. The parameters of the multiple OLS regression will be estimated based on the maximum likelihood method, while the hypothesis testing will be based on Wald statistic.

\section{The Results}

\subsection{Descriptive Statistics}

In Table 1, the summary of the descriptive statistics shows the mean, minimum and maximum scores for all the variables. On average, the dependent variable has scores of 0.5000 with minimum and maximum scores of 0 and 1 respectively. The mean scores for 14 of the variables are within acceptable range as the deviation from the standard is less than $200 \%$. However, for the remaining seven variables, the standard deviation exceeds $200 \%$ which shows higher deviations from the mean distribution. In particular, variables like dividend per share, price earnings and net book value per ordinary share have extreme deviations from the standard with values of 11.1211, 25.2377 and 11.9483 respectively. This is a clear indication that distribution within this data set is uneven as such, the likelihood of inaccurate prediction. Thus, the problem of heteroscedasticity. Finally, of the total 144 observations within the period of survey, price earnings ratio has the highest range (about 150), while debtor's turnover has the smallest range (0.2827).

\begin{tabular}{|c|c|c|c|c|}
\hline Variables & Mean & Standard deviation & Minimum & Maximum \\
\hline International financial reporting standards (IFRS) & 0.5000 & 0.5017 & 0.0000 & 1.0000 \\
\hline Current ratio & 1.0416 & 0.6087 & 0.0075 & 2.3683 \\
\hline Acid test ratio & 0.6417 & 0.4176 & 0.0058 & 1.6926 \\
\hline Stock turnover ratio & 5.6559 & 3.9123 & 0.0000 & 19.9576 \\
\hline Debtors turnover ratio & 0.1371 & 0.0740 & 0.0000 & 0.2876 \\
\hline Creditors turnover ratio & 0.3696 & 0.6965 & 0.0000 & 4.1692 \\
\hline Propriety ratio & 1.0515 & 1.1027 & -2.654 & 3.3202 \\
\hline Gearing ratio & 0.2088 & 0.2951 & 0.0000 & 1.1146 \\
\hline Interest gearing ratio & 0.1782 & 0.4789 & -0.7539 & 1.9569 \\
\hline Total liability to shareholders fund ratio & 1.2374 & 1.5372 & -2.9828 & 5.1154 \\
\hline Debt ratio & 2.2201 & 3.7819 & 0.3416 & 18.7001 \\
\hline Return on capital employed & 0.0548 & 0.2930 & -1.2688 & 0.3923 \\
\hline Gross profit margin & 0.2767 & 0.1539 & 0.0000 & 0.4965 \\
\hline Gross profit markup & 0.3998 & 0.3984 & -1.0000 & 0.9861 \\
\hline Net profit margin & 0.0603 & 0.1991 & -0.7748 & 0.3045 \\
\hline Expenses to sales ratio & 0.1892 & 0.1345 & 0.0000 & 0.5967 \\
\hline Dividend per share & 0.3990 & 11.1211 & 0.0000 & 65.2975 \\
\hline Dividend cover & 2.1975 & 4.4934 & 0.0000 & 24.8131 \\
\hline Earnings per share ratio & 2.8712 & 5.3734 & -1.4900 & 26.1500 \\
\hline Price earnings ratio & 18.8745 & 25.2377 & -14.3095 & 135.1563 \\
\hline Net book value per ordinary share & 9.7885 & 11.9483 & -4.6642 & 43.1337 \\
\hline
\end{tabular}

Source: Computed by the author using Stata 13 .

\subsection{Correlation Matrix/Index}

Table 2 indicates the correlation index of the data on the relationship exists between the independent variable (IFRS) adoption and all the dependent variables (predictors). This implies that the independent variables can influence the dependent variable. There exist six inverse relationships and 14 positive relationships. Those predictor variables with negative relationship are current ratio, acid test ratio, debt ratio, net profit margin, dividend per share and dividend cover ratio. For these variables, an increase in IFRS adoption leads to a 
corresponding decrease in their values. This means that IFRS adoption is having a negative impact on their value. The opposite is true for the remaining 14 dependent variables.

The result of the correlation matrix also shows that all the relationships are weak as none of them exceeds $20 \%$ in strength. Furthermore, of the entire relationships only two are significant (current ratio and net book value per ordinary share). In addition, a look at the relationship between the variables shows some elements of collinearity on the relationship between current ratio and acid test ratio (86.01\%); and that between proprietary ratio and total liability to shareholder's fund $(85.76 \%)$.

Table-2. Correlation matrix of individual variables

\begin{tabular}{l|c}
\hline Variables & IFRS correlation index \\
\hline International financial reporting standards (IFRS) & 1.0000 \\
\hline Current ratio & $-0.1827^{*}$ \\
\hline Acid test ratio & -0.1620 \\
\hline Stock turnover ratio & 0.1025 \\
\hline Debtors turnover ratio & 0.1469 \\
\hline Creditors turnover ratio & 0.0023 \\
\hline Propriety ratio & 0.1614 \\
\hline Gearing ratio & 0.0256 \\
\hline Interest gearing ratio & 0.0202 \\
\hline Total liability to shareholders ratio & 0.0363 \\
\hline Debt ratio & -0.0184 \\
\hline Return on capital & 0.0378 \\
\hline Gross profit margin & 0.0026 \\
\hline Gross profit markup & 0.0677 \\
\hline Net profit margin & -0.0494 \\
\hline Expenses to sales ratio & 0.0571 \\
\hline Dividend per share & -0.1232 \\
\hline Dividend cover & -0.1180 \\
\hline Earnings per share ratio & 0.0501 \\
\hline Price earnings ratio & 0.0440 \\
\hline Net book value per share & $0.1854^{*}$ \\
\hline Source: Computed by the author using Stata13. &
\end{tabular}

\subsection{Trends in Increments after IFRS adoption}

The need to know the behaviour of the dependent variables after the adoption of IFRS in 2012 is of vital significance. It is possible that the adoption of IFRS increases the performance of some elements of the predictor variables or decreases the behaviour of others. The use of "independent T-test (I-T) and Jonckheere-Terpstra (J-T) test would go a long way in explaining this phenomenon. The table below shows the behaviour of the I-T test from the group statistics of the I-T test.

\subsection{The Impact of the Performance Relationship on IFRS}

The impact of IFRS relationship on firm performance would be viewed from two major perspectives from the multiple OLS regression. At first, the analysis will assess the categorical impact of the variables. Next, further analysis would examine the impact of the individual variables on the adoption of IFRS. Table 3 shows the four categories of firm attributes which include liquidity, long-term solvency, profitability and investors performances; and the overall firm economic performance (average firm performance). Under each category, five variables were observed for this study.

Table-3. Logistic categorical performance.

\begin{tabular}{l|c|c|c|c}
\hline \multirow{2}{*}{ Performance Category } & $\mathbf{F}$ & $\mathbf{R}^{\mathbf{2}}$ & \multirow{2}{*}{ Teta } & P \\
\cline { 2 - 3 } & Statistics & Statistics & \multirow{2}{*}{ Statistics } \\
\cline { 2 - 3 } & & $\mathbf{( \% )}$ & & 0.000 \\
\hline Liquidity performance & 0.4676 & 4.15 & 0.0664 & 0.000 \\
\hline Current ratio performance & 0.0000 & 2.34 & 0.2216 & 0.002 \\
\hline Acid test ratio performance & 0.0017 & 1.05 & 0.1349 & 0.008 \\
\hline Stock turnover performance & 0.0078 & 2.16 & 0.0217 & 0.028 \\
\hline Debtors turnover performance & 0.0277 & & & \\
\hline Source: Computed by the author using Stata13.
\end{tabular}

\section{Discussion and Conclusions}

This study aim to investigate the effects of international financial reporting standard (IFRS) on liquidity performance of food and beverages listed companies in Nigeria. The result of this study seems to demonstrate that adoption of international financial reporting standard have an effect to the liquidity performance of food and beverages listed companies in Nigeria. Under the liquidity category, the variables observed include current ratio, acid test ratio, stock turnover ratio, debtor's turnover and creditors turnover. Of these, it is only creditors turn over that is not significantly influence by IFRS. All other variables within this category show significant impact of IFRS. Current ratio and acid test ratio performances show an inverse relationship with IFRS, significant at $1 \%$ level of significance. For every increase in IFRS, adoption current ratio and acid test, rations will rise by $22.16 \%$ and $13.49 \%$ respectively. This is an indication that IFRS adoption leads to a rise in current and acid test ratios. On the other hand, stock turnover and debtor's turnover performances responded positively towards the introduction of IFRS with a $79.94 \%$ and $2.17 \%$ impact respectively. Nevertheless, while stock turnover is significant at $1 \%$ 
debtor's turnover ratio is significant at $5 \%$. The result of this study provides some empirical evidence that suggest positive relationship exists between IFRS adoption and liquidity performance of food and beverages listed companies in Nigeria. The findings of this study is in line with the findings of early studies by Fornell and Bookstein (1982) and Doyle (1994) and more recent studies by Jayashankar (2012); Subramanian and Gopalakrishna (2001); Odhiambo et al. (2015) and Agyapong (2015) that indicates the existence of positive relationship between IFRS adoption and liquidity performance of food and beverages listed companies. The findings of the study further appear to concur with the general view presented in the literature that suggests the linkage between IFRS adoption performance.

\section{References}

Abdul-Baki, G., J.B. Khanagha, S. Mohamad, T. Hassan and Z.M. Sori, 2014. Value relevance of earnings, book value and dividends in an emerging capital market: Kuwait evidence. Global Finance Journal, 23(3): 221-234.

Abdullahi, M., K. Chalmers, U. Nura, G. Clinch and J.M. Godfrey, 2017. Changes in value relevance of accounting information upon IFRS adoption: Evidence from Australia. Australian Journal of Management, 36(2): 151-173.

Adejoh, E. and K. Hasnah, 2014. The value relevance of IFRS in the European banking industry. Review of Quantitative Finance and Accounting, 36(3): 437-457.

Adelusi and Ibigbami, 2017. IFRS and performance of financial institutions in Nigeria. Journal of Finance and Accounting, 6(1): 65-76.

Adeuja, C., 2015. International accounting standards and accounting quality. Journal of Accounting Research, 46(3): 467-498.

Adeyemi, N., 2012. An empirical evaluation of accounting income numbers. Journal of Accounting Research, 6(2): 1-14.

Agyapong, G.K., 2015. Linking marketing capabilities with firm performance: evidence from Ghana ${ }^{\text {ee }} \mathrm{s}$ microfinance industry. Journal of Business and Enterprise Development, 5(1): 36-51.

Chen, Y., M.Y. Abubakar, N. Abdulsallam and M.Y. Alkali, 2010. Quality of accounting reporting after the IFRS adoption in Nigeria. International Journal of Business, Economics and Management, 3(1 1): 160-172.

Daske, K. and U. Gebhardt, 2006. Impact of the Nigerian capital market on the economy. European Journal of Accounting Auditing and Finance Research, 3(2): 88-96.

Donwa, Y., C.P. Burgstahler, J.D. Hanna, G.D. Richardson and R. Thompson, 2015. Earnings management to avoid earnings decreases and losses. Journal of Accounting and Economics, 24(1): 99-126.

Doyle, P., 1994. Marketing management and strategy. New York: Prentice Hall.

Fornell, C. and F.L. Bookstein, 1982. Two structural equation models: LISREL and PLS applied to consumer exit-voice theory. Journal of Marketing Research, 19(4): 440-452.Available at: https://doi.org/10.2307/3151718.

Imhofe, J., 2003. An investigation into factors determine performance of IFRS. Journal of Accounting and Management, 3(3): 53-62.

International Accounting Standard (IAS) Plus, 2010. Pros and Cons for Investors', Accounting and Business Research.

Jayashankar, P., 2012. Marketing strategies in the microfinance sector: A case study on hand in hand microfinance Pvt. Ltd. IUP Journal of Marketing Management, $11(3):$ 64-78.

Josiah, A., B. Nuru, M. Sani and G. Sunday, 2013. Accounting practices and organisational performance. Journal of Accounting, Business, and Economics, 2(1): 8-19.

Kanu, D., Y. Alkali, D. Umar and I. Isah, 2014. Financial reporting standards adoption and financial performance. Journal of Accounting and Business Research, 3(2): 221-235.

Latridis, L., 2010. The impact of the new accounting reporting among listed firms in Nigerian stock market. Asian Journal of Social Sciences and Management Studies, 4(1): 1-9.

Nneka, H. and D. Rotimi, 2012. Have IFRS contributed to an increased value-relevance? Uppsala University. Department of Business Studies, (1606). pp: 1-33.

Ocansey, A. and R. Enahoro, 2014. A comparison of the value-relevance of US versus non-US. American Journal of Accounting and Finance, 2(1): 18-27.

Odhiambo, O.J., F. Kibera and R. Musyoka, 2015. The influence of organizational culture and marketing capabilities on performance of microfinance institutions in Kenya. Journal of Marketing Management, 3(1): 91-99.Available at: https://doi.org/10.15640/jmm.v3n1a9.

Oseni, S., 2013. Comparative evidence on the value relevance of IFRS-based accounting information in Germany and the UK. Journal of International Accounting, Auditing and Taxation, 2(8): 111-124.

Outa, M., 2011. Stock prices and accounting information: Evidence from Malaysia. Asian Review of Accounting, 16(2): 109-133.

Pius, K. and J. Raymond, 2014. Value accounting: Evidence from investment securities and the market valuation of banks. The Accounting Review, 69(1): 1-25.

Subramanian, R. and P. Gopalakrishna, 2001. The market orientation-performance relationship in the context of a developing economy: An empirical analysis. Journal of Business Research, 53(1): 1-13.Available at: https://doi.org/10.1016/s0148-2963(99)00109-5.

Taiwo, M. and A. Adejare, 2014. Accruals, cash flows, and equity values. Review of Accounting Studies, 4(3): $205-229$.

Umobong, B. and Z. Akani, 2015. Value-relevance of banks' fair value disclosures under SFAS No. 107. Accounting Review. 